\title{
Air Emergency Transport under COVID-19: Impact, Measures, and Future
}

\author{
Zhun Li (iD ${ }^{1,2}$ \\ ${ }^{1}$ School of Economics and Business Administration, Chongqing University, Chongqing 400030, China \\ ${ }^{2}$ Postdoctoral Programme, Chongqing Airport Group Co., Ltd., Chongqing 401120, China \\ Correspondence should be addressed to Zhun Li; i-chn-e@163.com
}

Received 26 February 2021; Revised 30 July 2021; Accepted 31 August 2021; Published 22 September 2021

Academic Editor: Yong Wang

Copyright (c) 2021 Zhun Li. This is an open access article distributed under the Creative Commons Attribution License, which permits unrestricted use, distribution, and reproduction in any medium, provided the original work is properly cited.

The COVID-19 pandemic caused by SARS-CoV-2 dominated the year 2020 and has an unprecedented impact on global air transport. This paper tries to make an overall review on the interaction of air transport and the COVID-19 pandemic. Although the confirmed cases were first reported in China, the origin of the pandemic remains uncertain. China was the first country to control the COVID-19 pandemic, and domestic air traffic recovers at a fast pace. Compared to 2019 level, world scheduled capacity, passengers carried, and revenues for 2020 were reduced by 50\%, 60\%, and $\$ 371$ billion, respectively. Compared with domestic passenger traffic, international passenger traffic reduces more seats, passengers, and revenues. Because air transport contributes to economic growth, many countries or regions provide aviation bailout. The US provides most direct aid, while China mostly provides policy measures. In the post-COVID-19 period, IATA suggests that accepting vaccinated passengers is the best practice to reopen borders. Air cargo will play an important role in the distribution of COVID-19 vaccines. Meanwhile, air transport should be more digitalized, sustainable, and responsible in the future.

\section{Introduction}

In the past several years, global air transport rapidly develops. According to the World Bank, the number of passengers carried increased from 0.31 billion in 1970 to 4.40 billion in 2019 [1]. The increasing passenger demand promotes the industry revolution and changes the ecosystem. For example, low-cost airlines are gaining more market share, which are different from full-service airlines servicing in segmentation of passengers [2]. During the process of growth, the air transport industry is always under the exposure of endogenous risks [3] and has undergone disasters and crises, such as 911 terrorist attacks, severe acute respiratory syndrome (SARS), H1N1, and Middle East respiratory syndrome. But the growth almost never stopped before the coronavirus disease 2019 (COVID-19) pandemic [4]. The global air transport industry operated as many as 38 million commercial flights and serviced 4.3 billion passengers in 2018 [5]. In addition, the sector employed 65.5 million people including 10.5 million staff in airlines and airports in 2019 [6].
However, the growth of air transport peaked in 2019. The COVID-19 pandemic broke out at the end of 2019, which was caused by a novel coronavirus known as SARS-CoV-2 [7]. The COVID-19 pandemic dominated the year 2020 and still evolves in this year. The pandemic has extensive and farreaching impacts on both individuals and society. The International Civil Aviation Organization (ICAO) shows that COVID-19 is an unprecedented shock and hits hard the air transport industry. Compared to the 2019 level before COVID-19, the world air passengers including international and domestic passengers declined $60 \%$ in 2020 [8]. According to the Center for Systems Science and Engineering at Johns Hopkins University, global confirmed COVID-19 cases surpassed 100 million by January 26, 2021 [9]. However, the waves of COVID-19 are not over yet. Several variants of the virus are creating concern. These SARS-CoV-2 variants first emerged in the UK, South Africa, and Brazil and have spread to the rest of the world [10].

COVID-19 is similar to SARS, both of which are airborne diseases resulting from human-to-human 
transmission [11]. However, these two viruses are completely different [12]. Although COVID-19 is less severe than SARS, the former is found to be more contagious than the latter [13-16]. Before outbreak of the COVID-19 epidemic, SARS was the first deadly coronavirus pandemic with the ability of human-to-human transmission [17].

SARS is caused by SARS coronavirus (SARS-CoV) $[18,19]$. A detailed chronology of SARS has been established [20]. The first known SARS case was confirmed in late 2002 in Guangdong province, China [21]. On February 21, 2003, a superspreader from Guangdong went to Hong Kong and communicated the virus to the nearby residents including 4 healthcare workers [22]. Because of international travel, the infected guests then carried SARS to Vietnam, Singapore, and Canada [23]. Within 6 months, the pandemic had spread to 28 more countries and regions in five continents: Asia, North America, Oceania, Europe, and Africa. Eventually, SARS disappeared rapidly benefiting from global cooperation and effective infection control measures. On April 28, 2003, Vietnam firstly ended SARS successfully. Hong Kong and China were declared SARS-free on June 23 and June 24, 2003, respectively. As the last human chain of SARS transmission was broken in Taiwan, China, the WHO announced the end of SARS epidemic on July 5, 2003. As of July 2003, the confirmed SARS cases were 8098 with 774 deaths across the world [24].

SARS did not hurt the air transport industry, as it rapidly bounced back. However, the air transport industry struggled to survive from the COVID-19 pandemic through the year 2020. Year 2020 was the most difficult year in history for the air transport industry. But it is the price we have to pay for controlling the COVID-19 pandemic. Travel restrictions play an important role in controlling the COVID-19 pandemic because international flights are one of the major drivers of international transmission of the pandemic [25]. By using COVID-19 air traffic visualization tool built by RAND Corporation, RAND found that about forty passengers per week exported this virus worldwide via international travel by the end of February 2020 [26].

It is necessary to summarize the economic impacts of COVID-19 on air transport, the roles of air transport in preventing COVID-19, and the future of air transport in the post-COVID-19 era. Tanriverdi et al. [27] reviewed the previous studies before COVID-19 published in the Journal of Air Transport Management. They used a bibliometric and visualization analysis and found that few studies focused on the combination of air transport and pandemics or crises. The results were surprising to Tanriverdi et al. [27]. The reason is that they expected that previous pandemics and crises never hit hard air transport like COVID-19 and thus the related studies are neglected. They also expected that the studies related to pandemic and transport would attract more attention in the future. Sun et al. [28] reviewed the short-term and long-term impact of COVID-19 on air transport and the role air transport plays in the spread of COVID-19. Meanwhile, they proposed 10 directions of future research regarding COVID-19 and air transport.

This paper first highlights some key moments during the COVID-19 pandemic, especially from the perspective of China. Second, this paper summarizes the roles of air restrictions in controlling COVID-19 and analyzes the negative impact of COVID-19 on air transport industry, especially Chinese civil aviation markets. The negative operating losses make airlines face rapid cash burn and then bankruptcy. However, because the air transport industry contributes to economic growth, aviation bailout is provided to help the industry. Air transport industry needs to evolve actively to adapt to changes in the post-COVID-19 era. This paper predicts the future of air transport industry finally.

This paper tries to make an overall review on the interaction of air transport and COVID-19 pandemic. This paper summarizes the roles of air restrictions in controlling the COVID-19 pandemic and performance of air transport industry during the COVID-19 pandemic. Because air transport is important for economic development, it gets government assistance. This paper tracks aviation bailout.

This paper also tries to contribute to highlighting the timeline of COVID-19 pandemic from the perspective of China. There are five stages of fighting against the epidemic for China. Thanks to the effective control of COVID-19 and policy support for civil aviation in China, China's domestic aviation market is recovering fast.

The rest of the paper is structured as follows. Section 2 looks back at the evolution of COVID-19 pandemic. Section 3 presents the impact of air transport on transmission of COVID-19, and Section 4 presents the impact of COVID-19 on the air transport industry. Section 5 introduces aviation bailout and the effectiveness to support air transport. Section 6 summarizes the relationship between air transport and economic growth. Section 7 predicts the future of air transport, and Section 8 concludes the paper.

\section{Timeline of COVID-19 Pandemic Developments}

On December 27, 2019, Hubei Provincial Hospital of Integrated Chinese and Western Medicine reported cases of pneumonia of unknown cause to the Wuhan Jianghan Center for Disease Prevention and Control. On December 31, China informed WHO about a cluster of pneumonia cases in Wuhan, Hubei province [29]. And, since that day, China began to release updates on the disease in accordance with the law. On January 7, 2020, a new type of coronavirus was identified as cause by Chinese authorities. As of January 19, 2020, China was in the first stage of fighting against the epidemic, where it of was swift response to the public health emergency.

The second stage, between January 20 and February 20, was the initial progress in containing the virus. During this period, newly confirmed cases in China rapidly increased. China began an all-out battle to protect Wuhan and Hubei from the COVID-19 epidemic. China mobilized nationwide resources to assist Hubei province and Wuhan city. On January 20, the National Health Commission (NHC) confirmed that the novel coronavirus could transmit from human to human and brings the pneumonia under quarantinable infectious disease management. On January 23, the Wuhan city's outbound routes at its airports and railway stations were closed temporarily at 10 a.m. and passenger 
traffic into Wuhan from other parts of China by road or waterway was suspended. On February 11, the WHO announced COVID-19 as the name of the disease and the virus causing COVID-19 was officially named "SARS-CoV-2." As the most comprehensive, stringent, and thorough epidemic prevention and control campaign was launched in China, the spread of the virus was curbed preliminarily. On February 19, newly cured and discharged cases outnumbered newly confirmed ones in Wuhan for the first time.

During the third stage, from February 21 to March 17, the rapid spread of virus was contained in Wuhan and Hubei province and the situation in other parts of China stabilized. However, the COVID-19 epidemic began to break out in other countries. On February 23, many Italian small towns entered a lockdown, and, on March 11, WHO declared COVID-19 a pandemic. However, from March 11 to March 17, the daily new confirmed cases in China remained in single digits and the epidemic peak had passed as a whole. To promote the stable development of air transport industry of China, on March 9, Civil Aviation Administration of China (CAAC) issues a series of support policies, including financial policies, charge reduction and burden alleviation, infrastructure investment, and so on. Some days later, US president Trump signed a $\$ 2$ trillion stimulus package called the CARES (Coronavirus Aid, Relief, and Economic Security) Act, in which air transport industry got more than $\$ 60$ billion.

The fourth stage, between March 18 and April 28, was an initial victory in a critical battle in defending Wuhan and Hubei against COVID-19. On March 18, there were no new domestic confirmed cases in China. However, on March 25, imported confirmed cases were reported in 23 provinces of China. To curb the spread of the virus, on April 1, nucleic acid testing was conducted on overseas arrivals at all points of entry. On April 8, Wuhan lifted 76-day outbound traffic restrictions and travel began to return to normal. By April 26, all COVID-19 patients in Wuhan hospitals had been discharged. Since this stage, China adopted an approach to guard against imported cases and a rebound in indigenous cases.

From April 29, China entered the fifth stage of ongoing prevention and control. The nationwide virus control was conducted on an ongoing basis. On May 1, WHO announced that the COVID-19 pandemic remains a public health emergency of international concern. However, on May 2, the public health emergency response was lowered to level 2 in Hubei province. It took China about 3 months to record a decisive victory in defending Wuhan city and Hubei province. This achievement did not come easily for China with its large population.

On May 14, global coronavirus death toll exceeded 300,000 according to Johns Hopkins University. On July 22, China launched the urgent use of COVID-19 vaccines. By the end of September, domestic air passengers carried nearly reached 2019 level in China [30]. As COVID-19 infections spiraled, Germany decided to impose national lockdown from November 2. Meanwhile, on December 14, a new SARS-CoV-2 variant was identified in UK, which could spread more readily between people [31]. On December 31,
Sinopharm COVID-19 vaccine got conditional market approval [32]. And, on February 6, 2021, China granted conditional market approval for Sinovac COVID-19 vaccine. In the United States, the U.S. Food and Drug Administration issued the first emergency use for Pfizer-BioNTech COVID19 vaccine on December 11, 2020 [33].

Because of the increasing number of confirmed cases caused by virus imposed from abroad, on January 6, Shijiazhuang city imposed a lockdown to curb infection. During Spring Festival, Chinese people were encouraged to stay put. On January 29, Shijiazhuang ended the lockdown for residents in low-risk areas. A World Health Organization report published on March 30 said that SARS-CoV-2 most likely transmits from bats to humans through other emissary animals and that a lab leak was extremely unlikely [34]. From mid-March, there was a sudden rise in the number of confirmed cases in India. On May 1, India reported a record daily rise of 401,993 new confirmed cases. Some days later, India had a new record high of 414,188 confirmed cases on May 7. In May, the COVID-19 pandemic suddenly broke out in Taiwan, China. On May 26, Taiwan, China, reported a total of 6,091 confirmed cases.

As of May, Guangzhou reported some COVID-19 cases infected by the Delta variant, which was first detected in India and is known to be highly transmissible. On June 2, Guangzhou raised the COVID-19 risk level of neighborhoods in Liwan, Panyu, and Haizhu districts. On June 25, all high-risk areas in China were cleared. Figure 1 highlights the timeline of COVID-19 as of June 2021.

\section{Roles of Air Restrictions in Containing COVID-19}

Facing the outbreak of COVID-19 pandemic, there is no choice but to implement bundles of protective measures which are highly restrictive and sometimes even intrusive in response to the spread of worldwide COVID-19 pandemic. Air travel is assessed to be possible to accelerate the spread of pandemic [35]. RAND estimates that COVID-19 transmits worldwide via international air flights [26]. China firstly identified COVID-19 and firstly took public measures to control the virus and prevent its human-to-human transmission. As COVID-19 rapidly spreads around the world, most governments adopt measures at various levels, including movement and travelling restrictions. Many studies explore the role of transport in the spread of infectious diseases and assess the role of travelling restrictions in controlling and limiting the COVID-19 pandemic.

To effectively manage the infectious diseases and assess the role of transport, Muley et al. [36] reviewed the literature related to infectious diseases and transport and analyzed the interaction of transport and the spread of infectious diseases. They found that transport plays a crucial role in controlling the spread of infectious diseases and transport sector is worst affected by the movement restrictions. Browne et al. [37] reviewed the role of transportation in the transmission of influenza and coronaviruses and found that, compared with road transport and sea transport, the propagation of influence can be accelerated and amplified by air transport. 


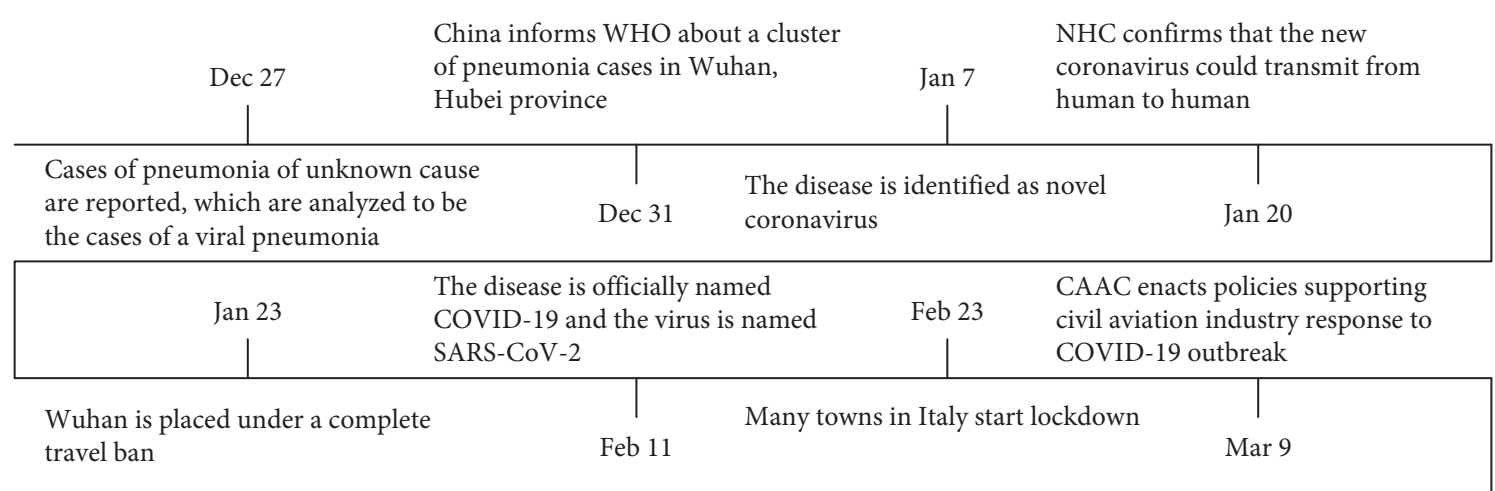

\begin{tabular}{|l|l|l|}
\hline \multicolumn{4}{|c|}{$\begin{array}{l}\text { No new domestic cases are } \\
\text { confirmed in China for the first time }\end{array}$} & \multicolumn{2}{c|}{$\begin{array}{l}\text { The last hospitalized Covid-19 } \\
\text { patient in Wuhan is discharged }\end{array}$} \\
$\begin{array}{l}\text { WHO declares COVID-19 a } \\
\text { pandemic }\end{array}$ & $\begin{array}{l}\text { Wuhan lifts 76-day outbound traffic } \\
\text { restrictions, and US daily new } \\
\text { confirmed cases surpass 42,000 }\end{array}$ & Apr 26 \\
\hline
\end{tabular}

\begin{tabular}{|c|c|c|c|c|c|}
\hline May 2 & \multicolumn{2}{|c|}{$\begin{array}{l}\text { A partial easing of the lockdown in } \\
\text { England }\end{array}$} & May 14 & \multicolumn{2}{|c|}{$\begin{array}{l}\text { A new daily record of } 115,228 \text { new } \\
\text { COVID-19 cases in Brazil }\end{array}$} \\
\hline $\begin{array}{l}\text { The public health emergency } \\
\text { response is lowered to Level } 2 \text { in } \\
\text { Hubei }\end{array}$ & May 10 & \multicolumn{3}{|c|}{$\begin{array}{l}\text { The worldwide coronavirus death } \\
\text { toll passes } 300,000\end{array}$} & Jun 24 \\
\hline Jul 22 & \multicolumn{2}{|c|}{$\begin{array}{l}\text { US passes } 6 \text { million COVID-19 } \\
\text { cases }\end{array}$} & Sep 30 & \multicolumn{2}{|c|}{$\begin{array}{l}\text { A partial lockdown begins in } \\
\text { Germany }\end{array}$} \\
\hline $\begin{array}{l}\text { China starts emergency use of } \\
\text { COVID-19 vaccine }\end{array}$ & Aug 31 & \multicolumn{3}{|c|}{$\begin{array}{l}\text { Domestic passengers nearly reach } \\
2019 \text { levels in China }\end{array}$} & Nov 2 \\
\hline
\end{tabular}

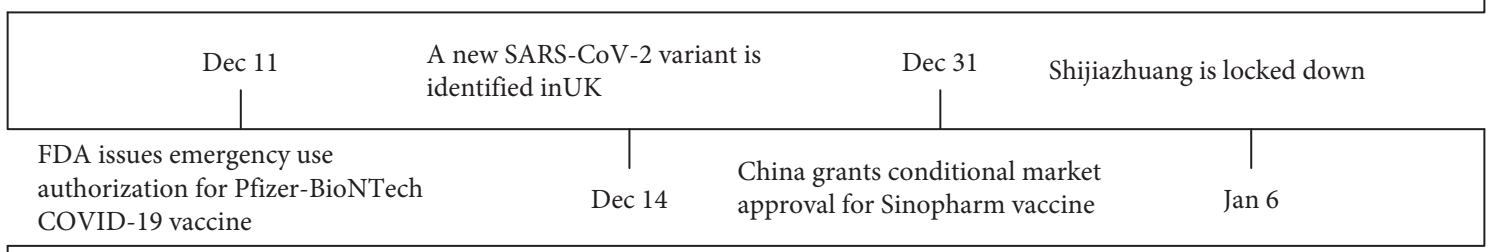

\begin{tabular}{|l|l|l|l|}
\hline \multicolumn{3}{|c|}{$\begin{array}{l}\text { China grants conditional market } 25 \\
\text { approval for Sinovac vaccine }\end{array}$} & $\begin{array}{l}\text { Mar } 30 \\
\text { A daily record rise of 401,993 new } \\
\text { confirmed cases in India }\end{array}$ \\
$\begin{array}{l}\text { China encourages people to stay put } \\
\text { during Spring Festival }\end{array}$ & $\begin{array}{l}\text { WHO report says that SARS-CoV-2 } \\
\text { most likely leapt from animals to } \\
\text { humans through an emissary animal }\end{array}$ & May 1 \\
\hline
\end{tabular}

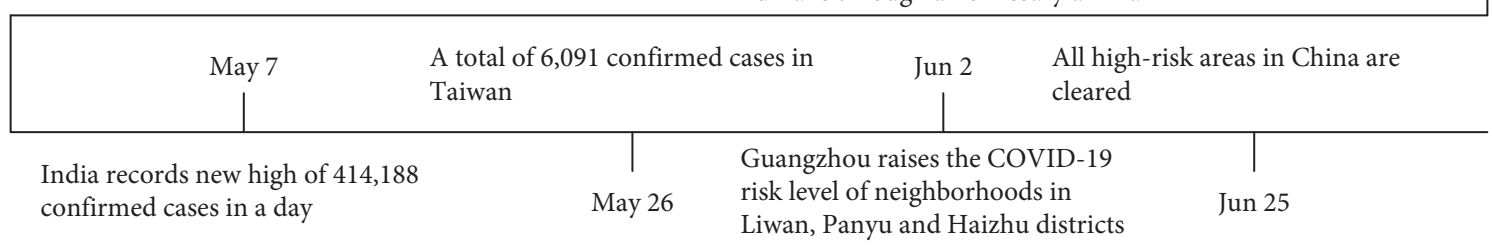

Figure 1: A timeline of COVID-19 during the period of 2019-2021.

The movement of travelers impacts the number of infected people and the duration of the epidemic [38]. Zhang et al. [39] found that the number of COVID-19 cases in the destinations was significantly related to the frequencies of air flights from Wuhan and that the speed of the spread of COVID-19 was also significantly associated with the presence of the airport. Many researches supported the view that travelling restrictions seem to be one of the most effective measures in restraining the spread of COVID-19. Linka et al. [40] showed that if travelling restrictions were not implemented with regard to the recent COVID-19 outbreak, the spread of COVID-19 could have been more serious, especially in France, Spain, and Central Europe. A shutdown of highly connected hub airports in biggest cities is effective to inhibit the spread the epidemic [41]. At the domestic level, the travelling restrictions can delay the outbreak by some 
days, and, at the international level, the travelling restrictions contribute to delaying the spread by a couple of weeks [42]. Especially at the early stage of the pandemic outbreak, travelling restrictions were found to be effective, while once the pandemic began to spread widely, the effectiveness of travelling restrictions became less [43]. Meanwhile, systematic reviews studied by Bielecki et al. [44] showed that the effect of travelling restrictions on limiting COVID-19 was limited generally and multiple factors affected the degree of impact, such as the extent and timing of restrictions, the epidemic size, the virus transmissibility, and travel patterns. They also pointed that temperature screening was not effective. Quarantine may delay the transmission of virus, but the effect is likely to be small. Saliva testing may be the best way to avoid quarantine after flight. Bajardi et al. [45] and Hollingsworth et al. [46] also found that travelling restrictions were of small a magnitude to affect the global spread of pandemic.

Apart from travelling restrictions, China was the first country to implement protective measures, some of which are worthy of reference. Shaw [47] overviewed the infection control practices during the 2003 SARS outbreak. The control measures included dedicated SARS hospitals [48], personal protective equipment [49, 50], isolation [51], physical space separation [52], handwashing [53], environmental decontamination [54], and education and training [55]. The lessons learned from 2003 SARS were helpful to control the spread of COVID-19.

Zhang et al. [56] summarized multiple levels of interventions including societal, community, organizational, and individual levels in Shanghai, China. Societal level strategy included reporting system and quarantine reinforcement, public health education, educational system support, and customs support. Both community health service centers and neighborhood committees played an important role in prevention efforts at a community level. Many public places were closed and all large public activities were suspended. Entertainment, exhibitions, lectures, and forums were provided online. Experts advised individuals to wear masks, open windows, wash hands frequently, and so on through mass media and social media. In addition, the use of serving chopsticks and spoons was called for by the government.

As the COVID-19 pandemic began to spread across the world, other countries and regions also implemented their protective measures. Several government interventions directly decreased contact probabilities, such as social distancing, bans on public events, self-isolation, and school closure. Meanwhile, other interventions included travelling restrictions and personal protective measures [57-61]. Haug et al. [62] ranked the effectiveness of these government interventions using a modelling approach that combines four different methods. Their study demonstrated that the imposed government interventions were necessary to suppress the spread of COVID-19, while there was a difference in their effectiveness. Among them, the most effective interventions comprised curfews, lockdowns, and gathering cancellations; and the highly effective and less intrusive measures included land border restrictions, support to the vulnerable, and risk-communication strategies.

\section{Impact of COVID-19 on Air Transport}

Global air transport sector makes great sacrifices to fight COVID-19. The social distancing and movement restriction measures, especially travelling restrictions, result in collateral damage to society, economy, and trade [62]. Due to the COVID-19 pandemic and travelling restriction measures, air transport suffers from a dramatic drop in demand. Bouali et al. [63] found that, in the period from January to April 2020, COVID-19 has significantly affected global passenger transport and air freight, resulting in losses and even bankruptcy. They are also expected to be worse in the coming years. In 2020, airlines were impacted by COVID19 , and many have ceased operation or gone bankrupt.

As expected by Bouali et al. [63], 2020 was a tough year for global air transport sector. Airports were estimated to lose approximately 64.2 of passenger traffic and $65 \%$ or more than 111.8 billion revenues in 2020 compared to business as usual [64], and airlines reduced revenue passenger kilometers by $65.9 \%$ in 2020 compared to 2019 [65]. Taken together, ICAO [8] reported that, compared to 2019 level, world scheduled capacity for year 2020 offered by airlines reduced by $50 \%$ overall, passengers carried reduced about 2.7 billion, and gross passenger operating revenues of airlines reduced about 371 billion dollars. Because travelling restrictions are mostly imposed on long-distant international flights, international flights suffer more seriously than domestic flights [66]. Therefore, compared with domestic passenger traffic, international passenger traffic reduces more seats and passengers and losses more revenues. Table 1 summarizes the scheduled passenger traffic for year 2020 .

There is a difference in air passenger traffic by region. As shown in Table 2, Asia and Pacific region seriously suffers from reduction of passengers and losses of revenues, falling by 921 million and 120 billion dollars, respectively. Europe and North America regions are not far behind.

The numbers of passengers carried by China's civil flight in 2020 was 418 million, which is about $63 \%$ of 2019 level [67]. The monthly evolution of China's passenger traffic from 2019 to 2021 is shown in Figure 2. Figure 2 shows that the numbers of passengers carried by domestic flights in February bottom out. Thanks to the effective control of the COVID-19 pandemic, China's domestic market has been recovering at faster pace since then. Domestic passenger traffic in September 2020 almost reached the level of the same period of last year. After a brief drop during Spring Festival in 2021, domestic passengers carried quickly recovered. The domestic passengers carried in March 2021 exceeded the level of the same period of 2019. However, because international travelling is still restricted by most countries, China's international passenger traffic has been in a low level since February 2020.

The performance of global air transport is barely satisfactory, which is reflected in stock market as well. Depending on the GARCH model, Liu et al. [68] found that the holistic volatility of index of Chinese airport shipping set increased compared to the pre-COVID-19 period and that there were significant differences in volatility of airports. In addition, the further evidences indicate that the more positive attitude 
TABLE 1: Change of world total air passenger traffic for year 2020 compared to 2019 level.

\begin{tabular}{lccc}
\hline & Airlines seats & Passengers & Airlines gross operating revenues \\
\hline Global & $-50 \%$ & 2,699 million $(-60 \%)$ & -371 billion dollars \\
International & $-66 \%$ & 1,376 million $(-74 \%)$ & -250 billion dollars \\
Domestic & $-38 \%$ & 1,323 million $(-50 \%)$ & -120 billion dollars \\
\hline
\end{tabular}

TABLE 2: Change of air passenger traffic for year 2020 compared to 2019 level by region.

\begin{tabular}{lccc}
\hline Region & Airlines seats & Passengers & Airlines gross operating revenues \\
\hline North America & $-43 \%$ & -599 million & -88 billion dollars \\
Asia and Pacific & $-45 \%$ & -921 million & -120 billion dollars \\
Europe & $-58 \%$ & -769 million & -100 billion dollars \\
Latin America and the Caribbean & $-53 \%$ & -199 million & -26 billion dollars \\
Middle East & $-60 \%$ & -132 million & -22 billion dollars \\
Africa & $-58 \%$ & -78 million & -14 billion dollars \\
\hline
\end{tabular}

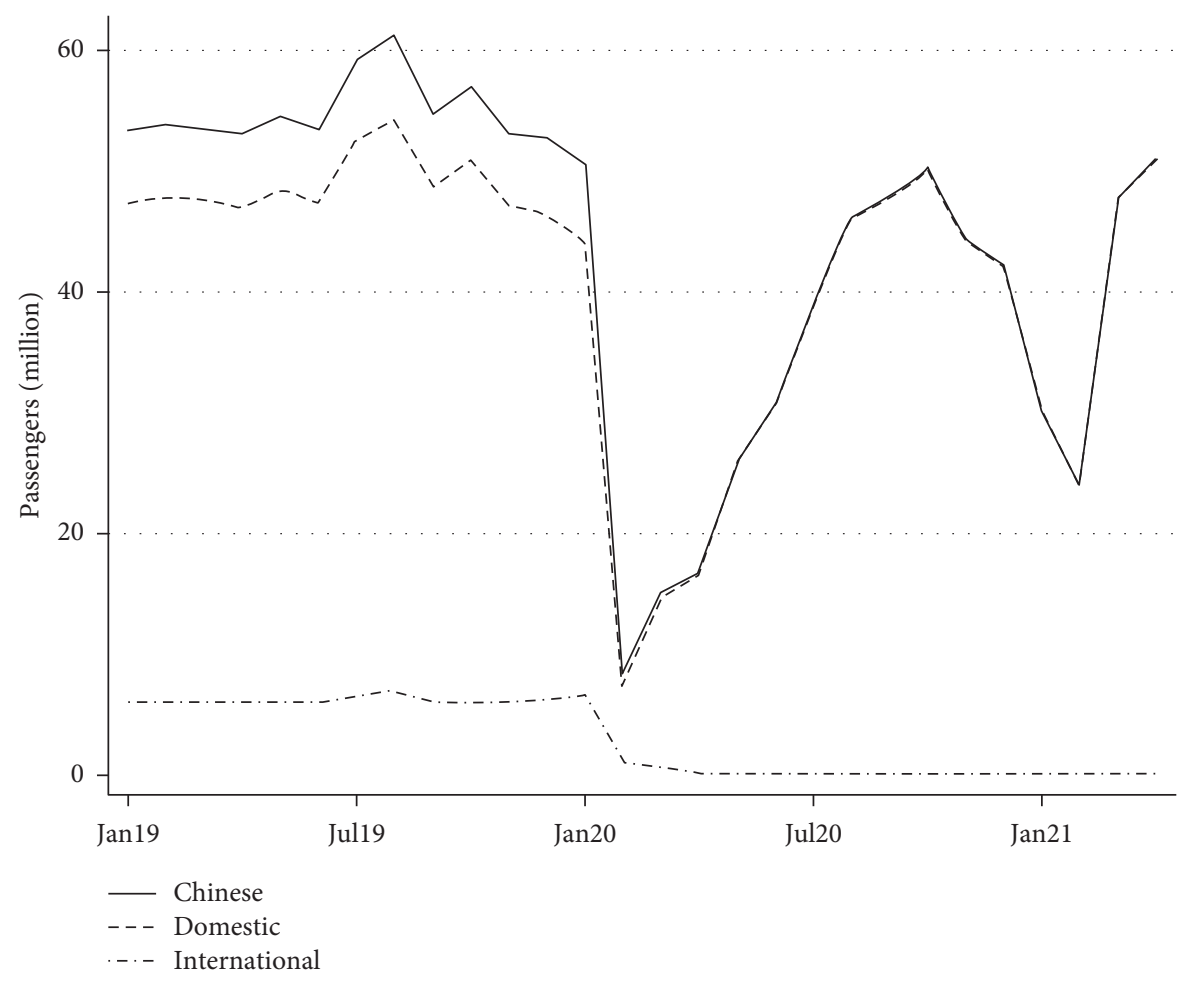

FIgURE 2: China's passenger traffic monthly evolution during the period of 2019-2021.

and more effective measures to mitigate risks of the diseases can decrease the stock price volatility. Maneenop and Kotcharin [69] demonstrated that the stock returns of 52 international listed airlines decrease more significantly than market returns and found that investors overreacted after the official announcements of WHO and President Trump.

The outbreak of COVID-19 also spilled over the employment in air transport industry and related industries, such as tourism. The reduction of capacity and loss of revenues of airlines rippled the airline employment. During the COVID-19 period, total airline employment is estimated to decrease by $7-13 \%$, with major airlines being worst affected [70]. World Tourism Organization (UNWTO) reports that, compared to 2019 level, international tourist arrivals reduced by 1 billion or by $74 \%$, international tourism revenues decreased by 1.3 trillion dollars, and 100-120 million tourism jobs were directly impacted. Moreover, international tourist arrivals plunged to 381 million, lower than 1990 level [71].

\section{Aviation Bailout}

As global air traffic activity plummeted, the cash holding of airlines and airports is rapidly burnt for the high capital costs. The share of fixed and semifixed costs of air transport industry picked up to $61 \%$ in 2020 and amortization and depreciation became the largest fixed operating cost [72]. Most of airlines have cash to maintain operation for only 
about two months [73]. However, civil aviation is seen as the strategic asset by many governments such as in Singapore, because it is closely related to other industries and economic growth. Meanwhile, during the COVID-19 pandemic, air transport plays an important role in stabilizing supply chains. Therefore, subsidies are provided to maintain air transport [74].

Many countries provide financial support to national airlines, airports and other participants in air transport sector. The support form can be divided into seven main categories, that is, government-backed commercial loans and government guarantees, recapitalization through state equity, flight subsidies and nationalization, deferral and/or waiver of taxes and charges, grants, and private equity [75]. Table 3 shows the government support provided by some countries and regions to airlines during the COVID-19 pandemic. As of August 2020, about 160 billion dollars were provided by governments to airlines [76]. The financial aid package for US airlines extends to more than 80 billion dollars, much more compared to other countries. Germany, France, Italy, and some other European countries intend to nationalize the large airlines in their countries to avoid being merged by other countries.

Abate et al. [75] explored the aim of government support to airlines in three dimensions of competition and liberalization, ownership and control, and environmental sustainability. In order to maintain essential connectivity and protect economy and employment, a few major airlines or/ and state-owned airlines obtain biggest financial support. Meanwhile most of low-cost and regional airlines only get a small part, which leads to an unfair competition and bankruptcy of small airlines. As shown in Table 4, at least 31 airlines ceased operation, went bankrupt, or filed for bankruptcy in 2020, all of which were low-cost airlines or regional airlines.

Apart from airlines, governments also provide support to airports, cargo airlines, general aviation, workers, and so on. Tables 5-7 show the measures to support airports, cargo carriers and general aviation, and workers, respectively. As shown in Table 5, more policy measures are provided in China, while the US, Singapore, and Norway provide direct aid to airports. The US provides $\$ 10$ billion grants-in-aid, Norway fully compensates the loss of airport charges, and Singapore allows airport to defer payment of fees.

Different from passenger flight, the pandemic leads to the increase in air cargo demand. To keep supply chains in foreign trade smooth, China provides effective policy measures to increase international air freight capacity. The US provides $\$ 4$ billion loans and loan guarantees for cargo carriers. Singapore rebates $10 \%$ landing charge for all scheduled freighter flights. In air transport industry, general aviation has not received sufficient attention [77]. Only US general aviation airports get $\$ 100$ million.

The US provides a total of $\$ 41.5$ billion grants for employee wages, salaries, and benefits, with $\$ 34.5$ billion for passenger airline employees, $\$ 4$ billion for cargo airline employees, and $\$ 3$ billion for airline contractor employees. Hong Kong, China, earmarks HK\$50 million to provide training allowance to frontline airport staff on no-pay leave.
Singapore pays $75 \%$ of the first $\$ \$ 4,600$ of monthly salaries per employee.

Overall, China and the US almost pay attention to each part in air transport industry. However, China mostly provides fee exemptions and policy measures, while the US provides direct aid with conditions. US aviation companies should avoid layoffs, maintain certain air service, and limit dividends and executive compensation. Compared with the US, China should provide more direct aid to air transport industry.

\section{Air Transport and Economic Growth}

In Organization for Economic Co-operation and Development (OECD) countries, passenger and freight air transport only account for about $0.3 \%$ of value-added, yet the important roles in economic activity are made by the strong linkages with both upstream and downstream industries [76]. In addition, the economic growth also generates demand for air transport and accelerates the development of air transport. The key point in the field is whether there is causal relationship between air transport and the economy. Tam and Hansman [78], Britton et al. [79], and Laird and Mackie [80] established a conceptual framework consisting of major channels where air transport and economy interact. Air transport impacts economy through supply chain effect and spillover effect, and economy accelerates air transport through feedback effects.

Irwin and Kasarda [81], Button et al. [82], Brueckner [83], Button and Yuan [84], and Brida et al. [85] found that there is a unidirectional causal relationship from air transport to economic growth. Fernandes and Pacheco [86] only found feedback effect from economy to air transport. Most studies found the evidences of bidirectional effect between air transport and economy [87, 88]. Zhang and Graham [89] found that the bidirectional effect is more likely to present in developing countries and there is only unidirectional effect from air transport to economies growth in developed countries.

In order to overcome the endogeneity problem better, McGraw [90] employed a pooled synthetic control event study strategy and found that airports can increase total employment by $3.9 \%$ per decade. Tveter [91] used difference in difference approach and estimated that the population of the city near the airports increased by 5\% from 1970 to 1980 . Apart from most studies at macro level, recently questions related to air transport at firm level are studied. Ellis et al. [92] introduced direct flights as an exogenous shock and found that the mutual funds invest significantly more in firms more proximate due to direct flights and these investments perform better.

\section{Development of Air Transport after COVID- 19}

COVID-19 vaccines are perhaps the best hope for limiting and even ending the epidemic. Before the presence of COVID-19 vaccines, the fresh waves of the epidemic continued. Gudmundsson et al. [93] showed that the most 
TABle 3: Measures to support airlines in some countries and regions.

\begin{tabular}{|c|c|c|}
\hline Country/region & Measures & $\begin{array}{l}\text { Effective date/ } \\
\text { duration }\end{array}$ \\
\hline \multirow{5}{*}{ China } & Waiver of Civil Aviation Development Fund payable by airlines & 1 Jan 2020 \\
\hline & $\begin{array}{l}\text { A subsidy of CNY } 0.0176 \text { per available seat-kilometer for cooperated international routes, and } \\
\text { a subsidy of CNY } 0.0528 \text { per available seat-kilometer for international routes covered by a sole } \\
\text { airline }\end{array}$ & $\begin{array}{l}\text { From } 23 \text { Jan to } 30 \text { Jun } \\
\qquad 2020\end{array}$ \\
\hline & Exemption of parking fees and $10 \%$ reduction of base price of landing \& take-off fees at classes & \\
\hline & $\begin{array}{l}1 \text { and } 2 \text { airports; } 10 \% \text { reduction of route fares; } 8 \% \text { reduction of base price of jet fuel sales } \\
\text { difference for domestic flights operated by domestic airlines }\end{array}$ & 23 Jan 2020 \\
\hline & Support for airlines' reorganization and optimization of capacity as required & 11 Feb 2020 \\
\hline \multirow{3}{*}{ Hong Kong, China } & $\begin{array}{l}\text { Full waiver for five months on parking and airbridge fees for idle passenger aircraft } \\
40 \% \text { reduction of passenger aircraft landing charges for four months }\end{array}$ & From Feb to Jun 2020 \\
\hline & Reduction of ramp handling, maintenance, and airside vehicle-related fees & \\
\hline & $\begin{array}{l}\text { Purchase of around 500,000 air tickets in advance from the four home-based airlines worth up } \\
\text { to HK\$2 billion }\end{array}$ & 8 Apr 2020 \\
\hline USA & $\begin{array}{l}\$ 25 \text { billion in loans and loan guarantees available to passenger airlines } \\
\$ 17 \text { billion in loans and loan guarantees to Boeing and its suppliers }\end{array}$ & 30 Mar 2020 \\
\hline \multirow[t]{2}{*}{ Singapore } & $\begin{array}{l}\text { 10\% landing charge rebate for all scheduled passenger flights landing in Singapore } \\
\text { 50\% rebate on rental paid for airlines' lounges and offices within Changi Airport and Seletar } \\
\text { Airport terminal buildings } \\
\text { 100\% rebate on aircraft parking charges at Changi Airport and Seletar Airport } \\
\text { Waivers of the 1\% increase in Landing, Parking, and Aerobridge (LPA) charges for all airlines } \\
\text { and freighter flights }\end{array}$ & $\begin{array}{l}\text { From Apr } 2020 \text { to } \\
\text { Mar } 2021\end{array}$ \\
\hline & $\begin{array}{l}\text { Deferred payment of certain fees such as certificates of airworthiness } \\
\text { Temasek Holdings will vote in favour of new issuance of shares and bonds and will buy all } \\
\text { remaining shares and bonds }\end{array}$ & 26 Mar 2020 \\
\hline \multirow{2}{*}{ Australia } & $\begin{array}{l}\$ 715 \mathrm{~m} \text { relief package to refund and waive aviation fuel excise, air service charges, and } \\
\text { domestic and regional aviation security charges }\end{array}$ & 17 Mar 2020 \\
\hline & $\begin{array}{c}\$ 198 \text { million to maintain critical air services throughout regional Australia by securing } \\
\text { operations to certain routes }\end{array}$ & 28 Mar 2020 \\
\hline \multirow{3}{*}{ New Zealand } & $\begin{array}{c}\text { NZ\$163 million financial support to pay passenger-based government charges for the next six } \\
\text { months }\end{array}$ & \\
\hline & $\begin{array}{l}\text { NZ\$37 million to cover airways related fees for the next six months } \\
\text { Any fee rises or pricing reviews from agencies that charge fees at the border are put on hold for } \\
12 \text { months }\end{array}$ & 17 Mar 2020 \\
\hline & NZ\$900 million government loan to Air New Zealand over the next two years & 20 Mar 2020 \\
\hline \multirow{4}{*}{$\begin{array}{l}\text { Germany } \\
\text { France \& } \\
\text { Netherlands } \\
\text { Italy } \\
\text { Sweden and } \\
\text { Denmark }\end{array}$} & $€ 9$ billion bailout to take $20 \%$ stake of Lufthansa & 25 May 2020 \\
\hline & $€ 10$ billion bailout to Air France-KLM & 24 Apr 2020 \\
\hline & $€ 600$ million bailout to Alitalia & 17 Mar 2020 \\
\hline & $\$ 300$ million credit guarantees to SAS & 17 Mar 2020 \\
\hline
\end{tabular}

pessimistic estimate of the recovery of passenger demand to pre-COVID-19 level will be in 2026 in the absence of vaccines. The demand for vaccines is almost certain to exceed the supply in 2021 [94]. International Air Transport Association (IATA) suggests that accepting vaccinated passengers is the best practice to reopen borders [95]. However, vaccine passports may worsen vaccine inequality [96]. Some high-income countries are already stockpiling vaccines [97], while low-income and middle-income countries urgently need vaccines [98]. Because inequitable vaccine distribution can cost lives and the global economy $[99,100]$, vaccine inequality should be righted and vaccines should be distributed equitably [101]. Air cargo plays a crucial role in distributing vaccines [102]. While just providing a single dose to 7.8 billion people needs 8,000 Boeing
747 cargo aircraft, and diminished cargo capacity of the global air transport industry likely limits the distribution of vaccines [103], it is necessary for vaccine distribution to establish emergency logistics with cost reduction and quick emergency response under limited transportation resources [104].

Another challenge for COVID-19 vaccine distribution is the cold chain transportation [105]. To ensure the quality of vaccines, the transportation must be in line with international regulatory requirements. The temperatures should be controlled. In every corner of the world, cold chain facilities are required and the scale of cold chain transportation is vast.

Although COVID-19 hits hard air transport, it promotes the rapid development and application of digitalization 
TABLE 4: List of bankruptcy of airlines in 2020.

\begin{tabular}{|c|c|c|}
\hline Airlines & Country/region & Date \\
\hline Trans States Airlines & USA & 1 Apr 2020 \\
\hline Compass Airlines & USA & 7 Apr 2020 \\
\hline Ravn & USA & Apr 2020 \\
\hline Miami Air International & USA & 8 May 2020 \\
\hline Shoreline Aviation & USA & 1 Apr 2020 \\
\hline ExpressJet & USA & 30 Sep 2020 \\
\hline Air Italy & Italy & $26 \mathrm{Feb} 2020$ \\
\hline Ernest Airlines & Italy & 13 Jan 2020 \\
\hline Flybe & UK & 5 Mar 2020 \\
\hline Germanwings & Germany & 7 Apr 2020 \\
\hline German Airways & Germany & 22 Apr 2020 \\
\hline SunExpress Deutschland & Germany & 26 Jun 2020 \\
\hline LEVEL Europe & Austria & 18 Jun 2020 \\
\hline Jet time & Denmark & 21 Jul 2020 \\
\hline Go2Sky & Slovakia & 21 Aug 2020 \\
\hline Montenegro Airlines & Republic of Montenegro & 24 Dec 2020 \\
\hline AtlasGlobal & Turkey & 12 Feb 2020 \\
\hline Cathay Dragon & Hong Kong, China & 21 Oct 2020 \\
\hline NokScoot & Thailand & 24 Jun 2020 \\
\hline Air Asia Japan & Japan & 5 Oct 2020 \\
\hline Palestinian Airlines & Palestine & 29 Dec 2020 \\
\hline Tigerair Australia & Australia & 5 Aug 2020 \\
\hline South African airways & South Africa & 6 Apr 2020 \\
\hline South African express & South Africa & 29 Apr 2020 \\
\hline Avianca Perú & Peru & 10 May 2020 \\
\hline TAME EP & Ecuador & 19 May 2020 \\
\hline Flyest & Argentina & 10 Jun 2020 \\
\hline LATAM Argentina & Argentina & 19 May 2020 \\
\hline One Airlines & Chile & 24 Jun 2020 \\
\hline Leeward Islands Air Transport & Antigua & 27 Jun 2020 \\
\hline
\end{tabular}

TABle 5: Measures to support airports in some countries and regions.

\begin{tabular}{|c|c|c|}
\hline $\begin{array}{l}\text { Country/ } \\
\text { region }\end{array}$ & Measures & $\begin{array}{c}\text { Effective date/ } \\
\text { duration }\end{array}$ \\
\hline China & $\begin{array}{c}\text { Restrictions on peak hour slots for cargo flights will be lifted at airports with strong cargo handling } \\
\text { capacity }\end{array}$ & 24 Mar 2020 \\
\hline USA & $\$ 10$ billion in grants-in-aid & 30 Mar 2020 \\
\hline Singapore & Deferred payment of certain fees such as licenses to provide air services & $\begin{array}{c}\text { From Apr } 2020 \text { to Mar } \\
2021\end{array}$ \\
\hline Norway & Fully compensating airports for the loss of airport charges & 19 Mar 2020 \\
\hline
\end{tabular}

technologies in air transport [106, 107]. Gallego and Font [108] used big data to assess the desire to travel and the intention to travel, demonstrating that big data should be widely used to improve management ability. Airports should accelerate implementation of biometric and contact-less capabilities to reduce human-to-human interactions after COVID-19 [109]. COVID-19 is rebuilding global economy and we cannot return to business as usual [110]. Digitalization is perhaps the only way out for air transport.

Global aviation is calculated to contribute to $3.5 \%$ of net anthropogenic effective radiative forcing in 2011 [111]. The
COVID-19 pandemic leads to the reduction in $\mathrm{CO}_{2}$ emissions of global air transport. Daily $\mathrm{CO}_{2}$ emissions by April 2020 declined by $60 \%$ in the aviation section compared with the mean 2019 level before COVID-19 [112]. However, air travel demand is estimated to continue to grow [8]. Green and sustainable transport receives more attention $[113,114]$. ICAO adopted the Carbon Offsetting and Reduction Scheme for International Aviation (CORSIA) in 2016 in order to offset $\mathrm{CO}_{2}$ emissions in international aviation [115]. Air transport should increase environmental sustainability $[116,117]$. Low-carbon technologies should be introduced to 
TABLE 6: Measures to support cargo carriers and general aviation in some countries and regions.

\begin{tabular}{lrr}
\hline Country/region & Measures & Effective date/duration \\
\hline China & $\begin{array}{c}\text { Policy support to international cargo flights during the outbreak } \\
\text { Encourage the merger and reorganization of air freight and logistics firms }\end{array}$ & 24 Mar 2020 \\
\hline \multirow{2}{*}{ USA } & $\begin{array}{l}\$ 4 \text { billion in loans and loan guarantees for cargo carriers } \\
\$ 100 \text { million for general aviation airports }\end{array}$ & 30 Mar 2020 \\
\hline Singapore & $10 \%$ landing charge rebate for all scheduled freighter flights & From Apr to Oct 2020 \\
\hline
\end{tabular}

TABLE 7: Measures to support workers in some countries and regions.

\begin{tabular}{|c|c|c|}
\hline Country/region & Measures & Effective date/duration \\
\hline Hong Kong, China & $\begin{array}{l}\text { HK\$50 million in training allowance to frontline airport staff who are on no-pay leave } \\
\$ 25 \text { billion in grants for passenger airline employee wages, salaries, and benefits }\end{array}$ & 24 Mar 2020 \\
\hline \multirow[t]{2}{*}{ USA } & $\begin{array}{l}\$ 4 \text { billion in grants for cargo airline employee wages, salaries, and benefits } \\
\$ 3 \text { billion in grants for airline contractor employee wages, salaries, and benefits }\end{array}$ & 30 Mar 2020 \\
\hline & $\$ 9.5$ billion in additional funds to air carriers & 25 Apr 2020 \\
\hline Singapore & $75 \%$ wage subsidy & 26 Mar 2020 \\
\hline
\end{tabular}

the field of air transport, such as electric flight and sustainable alternative fuels [118, 119]. Gössling et al. [120] found that nonbiogenic synthetic fuels likely are the most viable option to completely phase out fossil fuels.

\section{Conclusions}

Air transport is hit hard by COVID-19 and plays an important role in containing COVID-19. This paper tries to make an overall review on the interaction of air transport and COVID-19 pandemic. The confirmed cases were firstly found in China in December 2019 and then found in other countries. International flight accelerates the worldwide spread of the COVID-19 pandemic. Dependent on the lessons learnt from previous pandemics such as SARS, China and then other countries or regions quickly respond and implement several involuntary measures including travel restrictions to prevent COVID-19.

This paper first highlights some key moments during the COVID-19 pandemic, especially from the perspective of China. China experiences five stages fighting against the epidemic. Thanks to the effective control of COVID-19 and policy support for civil aviation in China, China's domestic aviation market is recovering fast. Second, this paper analyzes the impact of air transport on transmission of COVID19 and the roles of air restrictions in controlling COVID-19. As a result, the grounding of aircrafts causes immense operating losses of each part in air transport industry because the fixed costs of the sector are high.

Third, this paper summarizes the negative impact of COVID-19 on air transport industry, especially Chinese civil aviation markets. The data of Chinese passenger traffic shows that domestic passengers carried since February 2020 recovered. And domestic passenger traffic in September 2020 almost reached the level in the same period of the preceding year. Compared to 2019 level, world scheduled capacity for year 2020 offered by airlines reduced by $50 \%$ overall, passengers carried reduced about 2.7 billion, and gross passenger operating revenues of airlines reduced about 371 billion dollars.
The negative operating losses make airlines face rapid cash burn and then bankruptcy. Because air transport industry is seen as a key strategic asset and contributes to economic growth, aviation bailout is provided by governments to help air transport industry. Compared to other countries and regions, the US provided most direct aid. However, China mostly provides policy measures.

In the post-COVID-19 era, air transport industry itself needs to evolve actively to adapt to changes. For instance, more digitalization technologies should be applied and environmental sustainability be increased. In addition, air transport bears the burden of the distribution of COVID-19 vaccines. However, diminished cargo capacity of the global air transport industry likely limits the distribution of vaccines. Just providing a single dose to 7.8 billion people needs 8,000 Boeing 747 cargo aircraft. Meanwhile, the scale of cold chain transportation will be vast in the future.

\section{Conflicts of Interest}

The author declares that there are no conflicts of interest.

\section{Acknowledgments}

The author greatly acknowledges the helpful comments and suggestions of Professor Xu Maozeng from Chongqing Jiaotong University. This research was mainly sponsored by the Basic and Frontier Research Project of Chongqing (no. cstc2020jsyjzdxwtBX0003), Chongqing Social Science and Planning Priorities Project (no. 2020TBWT-ZD02), and Key Research Project of Chongqing Airport Group Co., Ltd. (no. 2019-3).

\section{References}

[1] World Bank, "Air transport, passengers carried," 2020, https://data.worldbank.org/indicator/IS.AIR.PSGR?end= 2019\&start $=1970 \&$ view $=$ chart.

[2] J. Pearson and R. Merkert, "Airlines-within-airlines: a business model moving East," Journal of Air Transport Management, vol. 38, pp. 21-26, 2014. 
[3] R. Merkert and H. Swidan, "Flying with (out) a safety net: financial hedging in the airline industry," Transportation Research Part E: Logistics and Transportation Review, vol. 127, pp. 206-219, 2019.

[4] L. H. Chung, "Impact of pandemic control over airport economics: reconciling public health with airport business through a streamlined approach in pandemic control," Journal of Air Transport Management, vol. 44, pp. 42-53, 2015.

[5] International Civil Aviation Organization, "Aviation benefits report 2019,” 2019, https://www.icao.int/sustainability/ Documents/AVIATION-BENEFITS-2019-web.pdf.

[6] Airports Council International and International Air Transport Association, "ACI and IATA call for urgent financial assistance to protect jobs and operations," 2020, https://www.iata.org/en/pressroom/pr/2020-04-30-01/.

[7] N. J. Matheson and P. J. Lehner, "How does SARS-CoV-2 cause COVID-19?” Science, vol. 369, pp. 550-551, 2020.

[8] International Civil Aviation Organization, "Effects of novel coronavirus (COVID-19) on civil aviation: economic impact analysis," 2021, https://www.icao.int/sustainability/ Documents/COVID-19/ICAO_Coronavirus_Econ_Impact. pdf.

[9] Johns Hopkins University, "COVID-19 dashboard by the Center for Systems Science and Engineering," 2020, https:// coronavirus.jhu.edu/map.html.

[10] J. Singh, J. Samal, V. Kumar et al., "Structure-function analyses of new SARS-CoV-2 variants B.1.1.7, B.1.351 and B.1.1.28.1: clinical, diagnostic, therapeutic and public health implications," Viruses, vol. 13, no. 3, p. 439, 2021.

[11] Y. Yang, H. Zhang, and X. Chen, "Coronavirus pandemic and tourism: dynamic stochastic general equilibrium modeling of infectious disease outbreak," Annals of Tourism Research, vol. 83, Article ID 102913, 2020.

[12] N. Zhu, D. Zhang, W. Wang et al., "A novel coronavirus from patients with pneumonia in China, 2019," New England Journal of Medicine, vol. 382, no. 8, pp. 727-733, 2020.

[13] W. J. Tan, X. Zhao, and X. J. Ma, "A novel coronavirus genome identified in a cluster of pneumonia cases-Wuhan, China 2019-2020," China CDC Weekly, vol. 2, pp. 61-62, 2020.

[14] C. I. Paules, H. D. Marston, and A. S. Fauci, "Coronavirus infections-More than just the common cold," Journal of the American Medical Association, vol. 323, no. 8, pp. 707-708, 2020.

[15] V. J. Munster, M. Koopmans, N. van Doremalen, D. van Riel, and E. de Wit, "A novel coronavirus emerging in China-key questions for impact assessment," New England Journal of Medicine, vol. 382, no. 8, pp. 692-694, 2020.

[16] The Novel Coronavirus Pneumonia Emergency Response Epidemiology Team, "The epidemiological characteristics of an outbreak of 2019 novel coronavirus diseases (COVID-19) in China," Chinese Journal of Epidemiology, vol. 41, no. 2, pp. 145-151, 2020.

[17] P. Sampathkumar, Z. Temesgen, T. F. Smith, and R. L. Thompson, "SARS: epidemiology, clinical presentation, management, and infection control measures," Mayo Clinic Proceedings, vol. 78, no. 7, pp. 882-890, 2003.

[18] C. Drosten, S. Günther, W. Preiser et al., "Identification of a novel coronavirus in patients with severe acute respiratory syndrome," New England Journal of Medicine, vol. 348, no. 20, pp. 1967-1976, 2003.
[19] J. Peiris, S. Lai, L. Poon et al., "Coronavirus as a possible cause of severe acute respiratory syndrome," The Lancet, vol. 361, no. 9366, pp. 1319-1325, 2003.

[20] J. D. Cherry, "The chronology of the 2002-2003 SARS mini pandemic," Paediatric Respiratory Reviews, vol. 5, no. 4, pp. 262-269, 2004.

[21] M. Enserink, "SARS: chronology of the epidemic," Science, vol. 339, no. 6125, pp. 1266-1271, 2013.

[22] M. Chan-Yeung and W. C. Yu, "Outbreak of severe acute respiratory syndrome in Hong Kong Special Administrative Region: case report," BMJ, vol. 326, no. 7394, pp. 850-852, 2003.

[23] K. W. Tsang, P. L. Ho, G. C. Ooi et al., "A cluster of cases of severe acute respiratory syndrome in Hong Kong," New England Journal of Medicine, vol. 348, no. 20, pp. 1977-1985, 2003.

[24] World Health Organization, "Summary of probable SARS cases with onset of illness from 1 November 2002 to 31 July 2003," 2003, http://www.who.int/csr/sars/country/ table2003_09_23/en/.

[25] Y. M. Sokadjo and M. N. Atchadé, "The influence of passenger air traffic on the spread of COVID-19 in the world," Transportation Research Interdisciplinary Perspectives, vol. 8, Article ID 100213, 2020.

[26] C. A. Mouton, A. R. Grissom, J. P. Godges, and R. Hanson, "COVID-19 air traffic visualization: worldwide spread of COVID-19 accelerated starting on february 19," 2020, https:// www.rand.org/pubs/research_reports/RRA248-6.html.

[27] G. Tanriverdi, M. Bakır, and R. Merkert, "What can we learn from the JATM literature for the future of aviation post Covid-19? -A bibliometric and visualization analysis," Journal of Air Transport Management, vol. 89, Article ID 101916, 2020.

[28] X. Q. Sun, S. Wandelt, C. H. Zheng, and A. M. Zhang, "COVID-19 pandemic and air transportation: successfully navigating the paper hurricane," Journal of Air Transport Management, vol. 94, Article ID 102062, 2021.

[29] World Health Organization, "Novel coronavirus (2019nCoV) situation report-1," 2020, https://www.who.int/ docs/default-source/coronaviruse/situation-reports/20200121sitrep-1-2019-ncov.pdf.

[30] Civil Aviation Administration of China, "Statistics of key performance indicators for china's civil aviation industry in september 2020," 2020, http://www.caac.gov.cn/en/HYYJ/ SJ/202011/t20201123_205327.html.

[31] Department of Health and Social Care, "Sharp rise in coronavirus numbers and a new variant," 2020, https:// www.gov.uk/government/speeches/sharp-rise-in-coronavirusnumbers-and-a-new-variant.

[32] State Council, "China approves first self-developed COVID19 vaccine," 2020, http://english.www.gov.cn/news/topnews/ 202012/31/content_WS5fed6440c6d0f72576942c83.html.

[33] U.S. Food and Drug Administration, "Pfizer-BioNTech COVID-19 vaccine," 2021, https://www.fda.gov/emergencypreparedness-and-response/coronavirus-disease-2019-covid19/pfizer-biontech-covid-19-vaccine\#: :text=On\%20December \%2011\%2C\%202020\%2C\%20the\%20U.S.\%20Food\%20and,in\% 20individuals\%2016\%20years\%20of\%20age\%20and\%20older.

[34] World Health Organization, "WHO-convened global study of origins of SARS-CoV-2: China part," 2021, https://www. who.int/publications/i/item/who-convened-global-study-oforigins-of-sars-cov-2-china-part.

[35] R. F. Grais, J. Hugh Ellis, and G. E. Glass, "Assessing the impact of airline travel on the geographic spread of 
pandemic influenza," European Journal of Epidemiology, vol. 18, no. 11, pp. 1065-1072, 2003.

[36] D. Muley, M. Shahin, C. Dias, and M. Abdullah, "Role of transport during outbreak of infectious diseases: evidence from the past," Sustainability, vol. 12, no. 18, Article ID 7367, 2020.

[37] A. Browne, S. S. Ahmad, C. R. Beck, and J. S. Nguyen-VanTam, "The roles of transportation and transportation hubs in the propagation of influenza and coronaviruses: a systematic review," Journal of Travel Medicine, vol. 23, no. 1, Article ID tav002, 2016.

[38] A. Denphedtnong, S. Chinviriyasit, and W. Chinviriyasit, "On the dynamics of SEIRS epidemic model with transportrelated infection," Mathematical Biosciences, vol. 245, no. 2, pp. 188-205, 2013.

[39] Y. Zhang, A. Zhang, and J. Wang, "Exploring the roles of high-speed train, air and coach services in the spread of covid-19 in China," Transport Policy, vol. 94, pp. 34-42, 2020.

[40] K. Linka, M. Peirlinck, F. Sahli Costabal, and E. Kuhl, "Outbreak dynamics of COVID-19 in Europe and the effect of travel restrictions"' Computer Methods in Biomechanics and Biomedical Engineering, vol. 23, no. 11, pp. 710-717, 2020.

[41] L. Hufnagel, D. Brockmann, and T. Geisel, "Forecast and control of epidemics in a globalized world," Proceedings of the National Academy of Sciences, vol. 101, no. 42, pp. 15124-15129, 2004.

[42] M. Chinazzi, J. T. Davis, M. Ajelli et al., "The effect of travel restrictions on the spread of the 2019 novel coronavirus (COVID-19) outbreak," Science, vol. 368, no. 6489, pp. 395-400, 2020.

[43] M. U. G. Kraemer, C.-H. Yang, B. Gutierrez et al., "The effect of human mobility and control measures on the COVID-19 epidemic in China," Science, vol. 368, no. 6490, pp. 493-497, 2020.

[44] M. Bielecki, D. Patel, and J. Hinkelbein, "Air travel and covid-19 prevention in the pandemic and peri-pandemic period: a narrative review," Travel Medicine and Infectious Disease, vol. 39, Article ID 101915, 2021.

[45] P. Bajardi, C. Poletto, and J. J. Ramasco, "Human mobility networks, travel restrictions, and the global spread of 2009 H1N1 pandemic," PLoS One, vol. 6, Article ID 16591, 2011.

[46] T. D. Hollingsworth, N. M. Ferguson, and R. M. Anderson, "Will travel restrictions control the international spread of pandemic influenza?” Nature Medicine, vol. 12, no. 5, pp. 497-499, 2006.

[47] K. Shaw, "The 2003 SARS outbreak and its impact on infection control practices," Public Health, vol. 120, no. 1, pp. 8-14, 2006.

[48] P.-L. Ho, X.-P. Tang, and W.-H. Seto, "SARS: hospital infection control and admission strategies," Respirology, vol. 8, no. s1, pp. S41-S45, 2003.

[49] T. Svoboda, B. Henry, L. Shulman et al., "Public health measures to control the spread of the severe acute respiratory syndrome during the outbreak in Toronto," New England Journal of Medicine, vol. 350, no. 23, pp. 2352-2361, 2004.

[50] J. T. F. Lau, K. S. Fung, T. W. Wong et al., "SARS transmission among hospital workers in Hong Kong," Emerging Infectious Diseases, vol. 10, no. 2, pp. 280-286, 2004.

[51] E. Seow, "SARS: experience from the emergency department, Tan Tock Seng Hospital, Singapore," Emergency Medicine Journal, vol. 20, no. 6, pp. 501-504, 2003.
[52] G. Gopalakrishna, P. Choo, Y. S. Leo et al., "SARS transmission and hospital containment," Emerging Infectious Diseases, vol. 10, no. 3, pp. 395-400, 2004.

[53] W. Seto, D. Tsang, R. Yung et al., "Effectiveness of precautions against droplets and contact in prevention of nosocomial transmission of severe acute respiratory syndrome (SARS)," The Lancet, vol. 361, no. 9368, pp. 1519-1520, 2003.

[54] World Health Organization, "Consensus document on the epidemiology of severe acute respiratory syndrome (SARS)," 2003, http://www.who.int/csr/sars/en/WHOconsensus.pdf.

[55] M. R. Loutfy, T. Wallington, T. Rutledge et al., "Hospital preparedness and SARS," Emerging Infectious Diseases, vol. 10, no. 5, pp. 771-776, 2004.

[56] N. Zhang, T. Shi, H. Zhong, and Y. Guo, "Covid-19 prevention and control public health strategies in Shanghai, China," Journal of Public Health Management and Practice, vol. 26, no. 4, pp. 334-344, 2020.

[57] A. Arenas, W. Cota, and J. Gómez-Gardeñes, "Derivation of the effective reproduction number $r$ for covid-19 in relation to mobility restrictions and confinement," medRxiv, 2020.

[58] K. A. Auger, S. S. Shah, T. Richardson et al., "Association between statewide school closure and COVID-19 incidence and mortality in the US," Journal of the American Medical Association, vol. 324, no. 9, pp. 859-870, 2020.

[59] J. Y. Wang, K. Tang, K. Feng, and W. F. Lv, "When is the COVID-19 pandemic over? Evidence from the stay-at-home policy execution in 106 Chinese cities," SSRN Electronic Journal, 2020.

[60] J. P. R. Soucy, S. L. Sturrock, and I. Berry, "Estimating effects of physical distancing on the COVID-19 pandemic using an urban mobility index," medRxiv, 2020.

[61] S. C. Anderson, A. M. Edwards, and M. Yerlanov, "Quantifying the impact of COVID-19 control measures using a Bayesian model of physical distancing," PLoS Computational Biology, vol. 16, no. 12, Article ID 1008274, 2020.

[62] N. Haug, L. Geyrhofer, A. Londei et al., "Ranking the effectiveness of worldwide covid-19 government interventions," Nature Human Behaviour, vol. 4, no. 12, pp. 1303-1312, 2020.

[63] S. Bouali, S. Douha, and N. Khadri, "To what extent is air freight affected by the corona virus pandemic?" Journal of Sustainable Development of Transport and Logistics, vol. 5, no. 2, pp. 98-108, 2020.

[64] Airports Council International, The Impact of COVID-19 on the Airport Business, Airports Council International, Montreal, Canada, 2020, https://aci.aero/wp-content/uploads/ 2020/12/Advisory_Bulletin_The_impact_of_COVID_19_on_ the_airport_business.pdf.

[65] International Air Transport Association, "December 2020 air passenger market analysis," 2020, https://www.iata.org/en/ iata-repository/publications/economic-reports/air-passengermonthly-analysis---december-2020/.

[66] X. Q. Sun, S. Wandelt, and A. M. Zhang, "How did covid-19 impact air transportation? a first peek through the lens of complex networks," Journal of Air Transport Management, vol. 89, Article ID 101928, 2020.

[67] Civil Aviation Administration of China, "Statistical bulletin of civil aviation industry development in 2020," 2021, http://www.caac.gov.cn/XXGK/XXGK/TJSJ/202106/ t20210610_207915.html.

[68] J. Liu, P. Qiao, J. Ding et al., "Will the aviation industry have a bright future after the covid-19 outbreak? evidence from 
Chinese airport shipping sector," Journal of Risk and Financial Management, vol. 13, no. 11, p. 276, 2020.

[69] S. Maneenop and S. Kotcharin, "The impacts of covid-19 on the global airline industry:an event study approach,” Journal of Air Transport Management, vol. 89, Article ID 101920, 2020.

[70] J. B. Sobieralski, "Covid-19 and airline employment: insights from historical uncertainty shocks to the industry," Transportation Research Interdisciplinary Perspectives, vol. 5, Article ID 100123, 2020.

[71] World Tourism Organization, "COVID-19 and tourism," 2021, https://www.unwto.org/covid-19-and-tourism-2020.

[72] International Air Transport Association, "Shares of key cost items changed during the crisis," 2021, https://www.iata.org/ en/iata-repository/publications/economic-reports/shares-ofkey-cost-items-changed-during-the-crisis_/.

[73] International Air Transport Association, "Industry losses to top $\$ 84$ billion in 2020," 2020, https://www.iata.org/en/ pressroom/pr/2020-06-09-01/.

[74] J. Arellana, L. Márquez, and V. Cantillo, "COVID-19 outbreak in Colombia: an analysis of its impacts on transport systems," Journal of Advanced Transportation, vol. 2020, Article ID 8867316, 12 pages, 2020.

[75] M. Abate, P. Christidis, and A. J. Purwanto, "Government support to airlines in the aftermath of the covid-19 pandemic," Journal of Air Transport Management, vol. 89, Article ID 101931, 2020.

[76] Organization for Economic Co-operation and Development, "COVID-19 and the aviation industry: impact and policy responses," 2020, http://www.oecd.org/coronavirus/policyresponses/covid-19-and-the-aviation-industry-impact-andpolicy-responses-26d521c1/.

[77] L. Tisdall, Y. Zhang, and A. Zhang, "COVID-19 impacts on general aviation - comparative experiences, governmental responses and policy imperatives," Transport Policy, vol. 110, pp. 273-280, 2021.

[78] R. Tam and R. J. Hansman, "Impact of air transportation on regional economic and social connectivity in the United States," in Proceedings of the AIAA Aircraft Technology, Integration, and Operations Forum, Los Angeles, CA, USA, October 2002.

[79] E. Britton, A. Cooper, and D. Tinsley, "The economic catalytic effects of air transport in Europe," in Proceedings of the ETC 2005, Vilnius, Lithuania, November 2005.

[80] J. Laird and P. Mackie, Wider Economic Impacts of Regional Air Connectivity, Department for Transport, London, UK, 2018.

[81] M. D. Irwin and J. D. Kasarda, "Air passenger linkages and employment growth in U.S. Metropolitan areas," American Sociological Review, vol. 56, no. 4, pp. 524-537, 1991.

[82] K. Button, S. Lall, R. Stough, and M. Trice, "High-technology employment and hub airports," Journal of Air Transport Management, vol. 5, no. 1, pp. 53-59, 1999.

[83] J. K. Brueckner, "Airline traffic and urban economic development," Urban Studies, vol. 40, no. 8, pp. 1455-1469, 2003.

[84] K. Button and J. Yuan, "Airfreight transport and economic development: an examination of causality," Urban Studies, vol. 50, no. 2, pp. 329-340, 2013.

[85] J. G. Brida, D. Bukstein, and S. Zapata-Aguirre, "Dynamic relationship between air transport and economic growth in Italy: a time series analysis," International Journal of Aviation Management, vol. 3, no. 1, pp. 52-67, 2016.
[86] E. Fernandes and R. R. Pacheco, "The causal relationship between GDP and domestic air passenger traffic in Brazil," Transportation Planning and Technology, vol. 33, no. 7, pp. 569-581, 2010.

[87] M. Marazzo, R. Scherre, and E. Fernandes, "Air transport demand and economic growth in Brazil: a time series analysis," Transportation Research Part E: Logistics and Transportation Review, vol. 46, no. 2, pp. 261-269, 2010.

[88] M. M. Hakim and R. Merkert, "The causal relationship between air transport and economic growth: empirical evidence from South Asia," Journal of Transport Geography, vol. 56, pp. 120-127, 2016.

[89] F. Zhang and D. J. Graham, "Air transport and economic growth: a review of the impact mechanism and causal relationships," Transport Reviews, vol. 40, no. 4, pp. 506-528, 2020.

[90] M. J. McGraw, "The role of airports in city employment growth, 1950-2010," Journal of Urban Economics, vol. 116, Article ID 103240, 2020.

[91] E. Tveter, "The effect of airports on regional development: evidence from the construction of regional airports in Norway," Research in Transportation Economics, vol. 63, pp. 50-58, 2017.

[92] J. Ellis, L. Madureira, and S. Underwood, “The causal effects of proximity on investment: evidence from flight introductions," Journal of Financial and Quantitative Analysis, vol. 55, no. 6, pp. 1978-2004, 2020.

[93] S. V. Gudmundsson, M. Cattaneo, and R. Redondi, "Forecasting temporal world recovery in air transport markets in the presence of large economic shocks: the case of COVID19," Journal of Air Transport Management, vol. 91, Article ID 102007, 2021.

[94] T. Burki, "Equitable distribution of COVID-19 vaccines," The Lancet Infectious Diseases, vol. 21, no. 1, pp. 33-34, 2021.

[95] International Air Transport Association, "Accepting vaccinated passengers should be best practice to reopen borders," 2021, https://www.iata.org/en/pressroom/pr/ 2021-05-19-01/.

[96] E. Stoye, "Daily briefling: vaccine passports could worsen inequality," Nature, vol. 12, 2021.

[97] A. D. So and J. Woo, "Reserving coronavirus disease 2019 vaccines for global access: cross sectional analysis," $B M J$, vol. 371, Article ID m4750, 2020.

[98] Lancet Commission on COVID-19 Vaccines and Therapeutics Task Force Members, "Urgent needs of low-income and middle-income countries for COVID-19 vaccines and therapeutics," Lancet, vol. 397, pp. 562-564, 2021.

[99] J. Lambert, "Global inequity in COVID-19 vaccination is more than a moral problem," Science News, vol. 199, no. 6, 2021.

[100] World Health Organization, "Vaccine inequity undermining global economic recovery," 2021, https://www.who. int/news/item/22-07-2021-vaccine-inequity-underminingglobal-economic-recovery.

[101] M. Bolcato, D. Rodriguez, and A. Feola, "COVID-19 pandemic and equal access to vaccines," Vaccines, vol. 9, no. 6, 2021.

[102] G. Nhamo, K. Dube, and D. Chodzi, Counting the Cost of COVID-19 on the Global Tourism Industry, Springer, Berlin, Germany, 2020.

[103] International Air Transport Association, "The time to prepare for COVID-19 vaccine transport is now," 2020, https:// www.iata.org/en/pressroom/pr/2020-09-09-01/. 
[104] Y. Wang, S. G. Peng, and M. Xu, "Emergency logistics network design based on space-time resource configuration," Knowledge-Based Systems, vol. 223, Article ID 107041, 2021.

[105] D. Dai, X. Wu, and F. Si, "Complexity analysis of cold chain transportation in a vaccine supply chain considering activity inspection and time-delay," Advances in Difference Equations, vol. 1, 2021.

[106] J. Li, Z. Z. Peng, and A. Liu, "Analysis and future challenge of blockchain in civil aviation application," in Proceedings of the IEEE 6th International Conference on Computer and Communications (ICCC), pp. 1742-1748, Chengdu, China, December 2020.

[107] Y. L. Wang and J. Sarkis, "Emerging digitalisation technologies in freight transport and logistics: current trends and future directions," Transportation Research Part E: Logistics and Transportation Review, vol. 148, Article ID 102291, 2021.

[108] I. Gallego and X. Font, "Changes in air passenger demand as a result of the COVID-19 crisis: using Big Data to inform tourism policy," Journal of Sustainable Tourism, vol. 2, pp. 1-20, 2020.

[109] F. Serrano and A. Kazda, "The future of airports post COVID-19," Journal of Air Transport Management, vol. 89, Article ID 101900, 2020.

[110] McKinsey \& Company, "COVID-19: implications for business," 2021, https://www.mckinsey.com/business-functions/ risk/our-insights/covid-19-implications-for-business.

[111] D. S. Lee, D. W. Fahey, and A. Skowron, "The contribution of global aviation to anthropogenic climate forcing for 2000 to 2018," Atmospheric Environment, vol. 244, Article ID 117834 , 2021.

[112] C. Le Quéré, R. B. Jackson, M. W. Jones et al., “Temporary reduction in daily global $\mathrm{CO} 2$ emissions during the COVID19 forced confinement," Nature Climate Change, vol. 10, no. 7, pp. 647-653, 2020.

[113] Y. Wang, S. G. Peng, and X. S. Zhou, "Green logistics location-routing problem with eco-packages," Transportation Research Part E: Logistics and Transportation Review, vol. 143, Article ID 102118, 2020.

[114] H. Zhang, C. X. Zhuge, and J. M. Jia, "Green travel mobility of dockless bike-sharing based on trip data in big cities: a spatial network analysis," Journal of Cleaner Production, vol. 313, Article ID 127930, 2021.

[115] International Civil Aviation Organization, "Carbon offsetting and reduction scheme for international aviation," 2021, https://www.icao.int/environmental-protection/ CORSIA/Pages/default.aspx.

[116] S. Gössling, "Risks, resilience, and pathways to sustainable aviation: a COVID-19 perspective," Journal of Air Transport Management, vol. 89, Article ID 101933, 2020.

[117] L. Budd and S. Ison, "Responsible transport: a post-COVID agenda for transport policy and practice," Transportation Research Interdisciplinary Perspectives, vol. 6, Article ID 100151, 2020.

[118] A. W. Schäfer, S. R. H. Barrett, K. Doyme et al., "Technological, economic and environmental prospects of all-electric aircraft," Nature Energy, vol. 4, no. 2, pp. 160-166, 2019.

[119] P. Schmidt, V. Batteiger, A. Roth, W. Weindorf, and T. Raksha, "Power-to-liquids as renewable fuel option for aviation: a review," Chemie Ingenieur Technik, vol. 90, no. 12, pp. 127-140, 2018.

[120] S. Gössling, A. Humpe, F. Fichert, and F. Creutzig, "COVID19 and pathways to low-carbon air transport until 2050," Environmental Research Letters, vol. 16, Article ID 034063, 2021. 